УДК 629.4.083:629.4.027.5

\title{
ШЛЯХИ ПІВИЩЕННЯ ЕФЕКТИВНОСТІ РОБОТИ РЕМОНТНОГО ВАГОННОГО ДЕПО
}

Канд. техн. наук І.Д. Борзилов, Ю.А. Зайцев

\section{ПУТИ ПОВЫШЕНИЯ ЭФФЕКТИВНОСТИ РАБОТЫ РЕМОНТНОГО ВАГОННОГО ДЕПО}

Канд. техн. наук И.Д. Борзилов, Ю.А. Зайцев

\section{WAYS TO IMPROVE THE REPAIR DEPOTS}

\author{
Cand. of techn. sciences I.D. Borzilov, U.A. Zaitsev
}

Наведені результати досліджень аспектів підвищення ефективності роботи ремонтного вагонного депо та обгрунтувані заходи для досягнення поставленої мети в умовах реформування залізничної галузі.

Ключові слова: вагонне депо, ремонт, ефективність, спеціалізація, концентрація, інвестииії, собівартість.

Приведены результаты исследований аспектов повышения эффективности работы ремонтного вагонного депо и обоснованы мероприятия для достижения поставленной цели в условиях реформирования железнодорожной отрасли.

Ключевье слова: вагонное депо, ремонт, эффрективность, специализация, конџентрация, инвестиџии, себестоимость.

Results over of researches of aspects of increase of efficiency of work of repair carhouse are brought and measures are reasonable for achievement of the put purpose in the conditions of reformation of railway industry.

Keywords: railroad depot repair, efficiency, specialization, concentration, investment cost.

Постановка проблеми. Безліч способів підвищення ефективності виробничо-господарської діяльності ремонтного вагонного депо (ВЧДР) можна звести до трьох основних напрямків: підвищення технічного і технологічного рівня; підвищення рівня організації та управління; підвищення рівня знань та кваліфікації працівників.

Найважливішим аспектом підвищення ефективності роботи ВЧДР було i залишається підвищення технічного i технологічного рівня, основні напрямки якого такі: комплексний характер механізації виробництва, що найбільш ефективно сприяє зменшенню ручної праці; автоматизація виробництва; компьютеризація всіх сфер діяльності вагонного депо; впровадження принципово нових технологій ремонту вагонів та їх вузлів i деталей.

Значного підвищення ефективності роботи ВЧДР можна досягти шляхом спеціалізації та концентрації виробництва, 
що відбуваються в умовах реформування галузі.

Аналіз останніх досліджень і публікацій. За останні роки виконано достатньо досліджень, присвячених підвищенню ефективності роботи вагонного депо [1-3]. В той же час досліджень, що спрямовані на розкриття сутності та обгрунтування принципів оцінки ступеня спеціалізації та концентрації ремонтного виробництва, надто мало. В останніх дослідженнях i публікаціях щодо реформування вагонного господарства [4] також не в повній мірі ураховуються аспекти щодо підвищення ефективності роботи ремонтного вагонного депо.

Формування мети. Метою даної роботи є дослідження аспектів та наукове обгрунтування заходів щодо підвищення ефективності роботи ремонтного вагонного депо в умовах реформування галузі.

\section{Виклад основного матеріалу} дослідження. Проведений аналіз діяльності вагонного господарства дозволяє зробити висновок, що парк вантажних вагонів не відповідає потребам сьогодення. Вагони нового покоління мають значно більш високі техніко-економічні параметри, які дозволяють не тільки підвищити продуктивність вагонів, але й значно збільшити продуктивність праці в галузі. Разом 3 тим, для насичення залізниць вагонами нового покоління ще потрібен час, a тому, щоб забезпечити приріст обсягів перевезень, необхідне підвищення ефективності виробничо-господарської діяльності ВЧДР вже сьогодні.

Розвиток виробничої потужності депо відбувається за рахунок реконструкції, тобто посилення їх виробничої потужності. У зв'язку з цим велике значення має перш за все пошук резервів та максимальне використання існуючої виробничої потужності, тобто збільшення випуску вагонів із ремонту без додаткових інвестицій.

Під виробничою потужністю ВЧДР розуміють максимально можливий випуск вагонів із ремонту протягом визначеного часу (зміна, доба, місяць, рік) при відповідному стані розвитку техніки, рівня організації виробництва.

Виробнича потужність ВЧДР має задовольняти потреби в ремонті вагонів, на яких спеціалізується підприємство. У цьому зв'язку вирішення питань спеціалізації та розвитку депо повинно відбуватися 3 повним урахуванням особливостей забезпечення його об'єктами ремонту.

Виробнича потужність розраховується за виробничими площами вагоноскладальної дільниці (ВСД), тобто за наявністю ремонтних позицій (стійл), оскільки ця дільниця є головною і визначає результати роботи всього виробництва депо.

Зазвичай розрахунок потужності вагонного депо виконують за формулою

$$
M_{В ч д P}=250 \cdot m_{c} \cdot n_{3, \mu},
$$

де 250 - число робочих днів упродовж року;

$m_{c}-$ число ремонтних позицій (стійл) у вагоноскладальній дільниці;

$n_{3 м}$ - кількість змін роботи депо.

Завантаження потужності депо визначається 3 урахуванням приведення за працевитратами всіх видів ремонту, що виконуються в депо для різних типів вагонів 3 використанням коефіцієнтів приведення

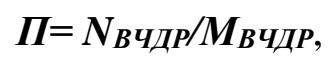

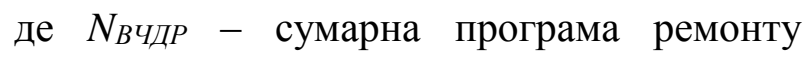
вагонів у депо, в приведених одиницях. приведення

3 урахуванням коефіцієнтів

$$
N_{B ч д P}=\sum\left(N^{\phi_{д P}} K_{n p}\right)_{i}+\sum\left(N^{\phi} K P^{\cdot} K_{n p}\right)_{i},
$$

де $N^{\phi}$ др - потреба в деповському ремонті $i$ го типу вагонів, од.; 
$N^{\phi}{ }_{K P}-$ потреба в капітальному ремонті $i$ го типу вагонів, од.;

$K_{n p}-$ коефіцієнт приведення для вагонів $i$-го типу, що ремонтують у депо.

Розрахунок потреби в планових обсягах ремонту виконується за формулами:

- деповський ремонт: $N^{\phi_{Д P}}=N_{n} \cdot \boldsymbol{K}_{д P}$,

- капітальний ремонт: $\boldsymbol{N}^{\boldsymbol{\phi}} \boldsymbol{K \boldsymbol { P }}=\boldsymbol{N}_{\boldsymbol{n}} \cdot \boldsymbol{K}_{\boldsymbol{K} \boldsymbol{P}}$, де $N_{n}$ - парк вантажних вагонів $i$-го типу на залізниці;

$K_{д P}$ та $K_{K P}-$ коефіцієнти деповського та капітального ремонту вагонів відповідно.

Як показує аналіз, в даний час ВЧДР переважно ремонтують вагони трьохчотирьох типів. Однак у ряді випадків 10$20 \%$ депо виконує ремонт п'яти-шести типів, а ремонт одного-двох - незначна кількість ВЧДР.

$\begin{array}{crr}\text { Для } & \text { узагальнення } & \text { характеристики } \\ \text { ВЧДР } & \text { пропонується } & \text { використання }\end{array}$ середньовагової величини кількості типів вагонів, що ремонтують у депо,

$$
p=\sum p_{i} \cdot a_{i} / \sum a_{i}
$$

де $p_{i}$ - питома вага $i$-го типу вагонів у загальному обсязі ремонту;

$a_{i}$ - питома вага вагонних депо, що ремонтують визначену кількість вагонів у загальній їх кількості, \%.

На підвищення кількості типів вагонів, що ремонтують у ВЧДР, впливає ремонт приватних та орендованих вагонів.

Поряд 3 подібною оцінкою можливо оцінювати спеціалізацію вагонних депо 3 урахуванням кількості вагонів, що ремонтуються. В цьому випадку середня кількість типів вагонів, що ремонтується в депо, розраховується таким чином:

$$
\boldsymbol{p}=\sum \boldsymbol{p}_{j} \cdot \kappa_{j} / \sum \kappa_{j}
$$

де $\kappa_{j}-$ питома вага кількості вагонів визначеного типу, що ремонтують у депо, в приведених одиницях, \%.

Розрізняють ступінь екстенсивного та інтенсивного використання виробничої потужності ВЧДР, тобто обладнання та виробничих площ депо.

Ступінь екстенсивного використання обладнання буде тим вище, чим більше часу воно працює та менше простоює.

Використання обладнання та виробничих площ, що характеризує випуск продукції в одиницю часу, $\epsilon$ показник інтенсивності використання обладнання та виробничих площ. Ступінь екстенсивного використання обладнання та виробничих площ характеризується, головним чином, змінністю роботи підприємств, а для вагонних депо - змінністю роботи виробництва, окремо складальних та заготівельних дільниць.

Середня змінність по залізницях вагоноскладальних дільниць вантажних вагонних депо порівняно невисока $-1,65$. Це пояснюється перш за все тим, що в даний час значна кількість ВЧДР працюють в однозмінному режимі виробництва. У зв'язку 3 цим $\epsilon$ можливість за умов переходу виробництва вагоноскладальних дільниць на двозмінний режим роботи збільшити загальний випуск вагонів більше ніж на $20 \%$ без будь-яких капітальних вкладень.

Змінність роботи заготівельних дільниць вагонних депо в середньому по залізницях не перевищує 1,5 , тобто трохи нижче, ніж у вагоноскладальних дільницях, що вказує на можливість забезпечити дані дільниці продукцією для вагоноскладальних дільниць при переході останніх на двозмінний режим роботи виробництва.

Найкращі показники інтенсивного використання обладнання та виробничих площ, що характеризують випуск продукції за одиницю часу (рік) з одного ремонтного стійла вагоноскладальної дільниці, досягаються в депо, у яких рівень концентрації та спеціалізації ремонту вагонів порівняно високий. Однак слід зазначити, що найбільші значення випуску продукції з одного ремонтного стійла в приведених вагонах у ВЧДР 3 більш 
високим рівнем концентрації ремонту досягнуті в основному за рахунок збільшення змінності роботи виробництва i в меншій мірі за рахунок інтенсивного використання обладнання та виробничої площі в одиницю часу. Це вказує на те, що у вагонних депо $\epsilon$ значні резерви щодо скорочення простою вагонів у деповському ремонті та збільшення за рахунок цього їх виробничої потужності.

Рівень концентрації ремонту вагонів впливає й на зміну структури основних виробничих фондів вагонного депо. Зі збільшенням програми ремонту вагонів питома вага активної частини основних виробничих фондів (обладнання, транспортні засоби та ін.) збільшується, а пасивна їх частина (будівлі та споруди, виробничий інвентар тощо) зменшується.

Зі збільшенням рівня концентрації ремонту за рахунок зниження питомої ваги пасивної частини основних виробничих фондів та кращого використання технологічного обладнання, зменшуються також питомі інвестиції в розрахунку на один вагон деповського ремонту.

Залежність питомих інвестицій на деповський ремонт вагонів від виробничої потужності вагонного депо визначають за формулою

$$
\boldsymbol{Y}=\boldsymbol{K}_{y n} / X+\boldsymbol{K}_{n i}
$$

де $\kappa_{y n}$ - сума умовної постійної частини інвестицій;

$\kappa_{n i}-$ питома величина змінних
інвестицій;

$\mathrm{X}$ - потужність вагонного депо в приведених вагонах деповського ремонту.

Залежність питомих інвестицій на деповський ремонт вагонів від виробничої потужності показує, що вона має тенденцію до зниження при збільшенні концентрації ремонту.

Питання залежності рівня собівартості одиниці продукції від обсягу його виробництва досліджувалися за допомогою розв'язання залежності

$$
C=B / N+a,
$$

де $C$ - собівартість одиниці продукції;

$B$ - сума умовно-постійних (незалежних) витрат;

$N$ - виробнича програма деповського ремонту вагонів;

$a$ - величина собівартості змінних (залежних) витрат від програми ремонту.

На сьогодні до залежних від обсягу продукції при розрахунках собівартості деповського ремонту вагонів відносять витрати на матеріали, покупні вироби, комплектуючі деталі та вузли вагона, заробітну плату виробничих робітників, технологічне паливо та електроенергію тощо.

До незалежних від обсягу продукції відносять витрати на опалення та освітлення приміщень депо, заробітну плату інженерно-технічного персоналу, витрати на експлуатацію будівлі і т. ін.

Питома вага вартості продукції заготівельних дільниць у загальних витратах на матеріали деповського ремонту вантажних вагонів складає від 30 до $75 \%$.

Залежність собівартості деповського ремонту вагонів від обсягу виробництва має гіперболічний характер. Наприклад, для ВЧДР при збільшенні випуску 3 деповського ремонту на 500 приведених вагонів, собівартість одиниці ремонту зменшується на $5 \%$.

Висновки. Значного підвищення ефективності роботи об'єктів інфраструктури ВЧДР можна досягти шляхом спеціалізації та концентрації виробництва, що відбувається в умовах реформування галузі.

Найкращі показники інтенсивного використання обладнання та виробничих площ, що характеризують випуск продукції за одиницю часу (рік) з одного ремонтного стійла складальної дільниці, досягаються в депо, у яких рівень концентрації та спеціалізації ремонту вагонів порівняно високий.

Залежність питомих інвестицій на деповський ремонт вагонів від виробничої потужності показує, що вона має тенденцію 
до зниження при збільшенні концентрації ремонту.

Залежність собівартості деповського ремонту вагонів від обсягу виробництва має гіперболічний характер.
Вагонні депо 3 ремонту вантажних вагонів потребують значних інвестицій, i одним із шляхів вирішення цієї проблеми $\epsilon$ концентрація та спеціалізація ВЧДР.

\section{Список використаних джерел}

1. Борзилов, І.Д. Оцінка параметрів витрат на ремонт вагона протягом його життєвого циклу [Текст] / І.Д. Борзилов // зб. наук. праць. - Донецьк: ДонІЗТ, 2007. - Вип. 9. - С. 105-112.

2. Борзилов, І.Д. Концепція спеціалізації підприємств з технічного утримання вагонів [Текст] / І.Д. Борзилов, В.О. Міхієнко, М.Г. Котов // зб. наук. праць. - Донецьк: ДонІЗТ, 2008. - Вип. 14. - С. 108-114.

3. Борзилов, І.Д. Наукові основи реструктуризації виробничо-технічної бази технічного утримання вагонів [Текст] / І.Д. Борзилов // зб. наук. праць. - Донецьк: ДонІЗТ. - 2009. Вип. 17. - С. 87-96.

4. Шмаров, П.П. Основные результаты первого этапа реформирования вагонного хозяйства ОАО РЖД [Текст] / П.П. Шмаров, Н.А. Никулина, А.А. Вовк // Экономика ж.-д. транспорта. - 2004. - № 9.

Борзилов Іван Дмитрович, канд. техн. наук, професор кафедри вагонів.

Зайцев Юрій Анатолійович, слухач ІППК.

Borzilov I.D., cand. of techn. sciences; Zaitsev U.A. 